\title{
Produtividade em serviço: comunicação e competência agregando valor e fidelização no ramo hoteleiro e alimentício
}

\author{
Denise Alvarez, Dr \\ Universidade Federal Fluminense \\ Escola de Engenharia \\ Depto de Engenharia de Produção \\ denisealvarez@,vm.uff.br
}

\section{Camila Miranda Moreira \\ Engenheira de Produção (Ipiranga) \\ camilammb@ig.com.br}

\author{
Barbara Blanco \\ Engenheira de Produção (Abaccomm Brasil) \\ barbara.blanco@gmail.com
}

\section{Clarisse Mariana Medeiros}

Engenheira de Produção (Accenture)

clamariana@ig.com.br

\begin{abstract}
Propõe-se nesse texto explorar alguns aspectos da lógica do setor de serviços e sua relação com a gestão de competências a partir de dois casos: o setor de governança num hotel de luxo e um restaurante com alto giro localizado no centro da cidade do Rio de Janeiro. O questionamento sobre a importância dos funcionários de linha de frente (front office) na qualidade do pacote de valor ofertado levou a uma série de análises que tiveram como eixos norteadores a interação entre os diferentes universos de serviços e a influência da comunicação e das competências na geração de valor. A metodologia utilizada baseou-se em algumas etapas da Análise Ergonômica do Trabalho (AET) e na aplicação da Análise multicritério proposta por Gadrey (2001). Visando aproximar as empresas a um modelo de excelência, foram propostos critérios para a avaliação da produtividade em cada um dos setores.
\end{abstract}

Palavras-chave: competência; fidelização; serviços

This paper aims to better understand the logic behind the service sector from two study cases: the housekeeping department in a luxurious hotel and a restaurant with high turnover located downtown. A question about the importance of the front office in the quality of the value package offered took the study into a series of analysis as the interaction among the different service universes, the influence of communication and competences in the final value to the customer, the impact of sizing the production capacity on the queueing process and the interpretation of the performance goals. Seeking to bring close together the company to a model of excellence, criterias have been suggested to evaluate productivity in this sector and also some main points to the achievement of profit were discussed through quality of service rendering.

Keywords: competences; fidelity; services 


\section{Introdução}

Considerando-se como setor de serviço no Brasil o comércio, os transportes, as comunicações, as instituições financeiras, a administração pública e os aluguéis, verifica-se que a cada ano a participação de mão-de-obra nesse setor aumenta, chegando a quase $60 \%$ da população. Grandes empresas multinacionais ingressaram no mercado brasileiro recentemente, como as cadeias de hotéis e restaurantes, o que comprova a importância e o crescimento de serviços como hospedagem e alimentação. Segundo dados do Cadastro Geral de Empregados e Desempregados (CAGED), divulgado pelo Ministério do Trabalho e Emprego, o primeiro trimestre de 2004, gerou 347,4 mil oportunidades de trabalho e ficou marcado como o melhor desempenho do nível de emprego com carteira assinada desde 1992. Todos os setores de atividade tiveram expansão do emprego formal, mas dois setores se destacaram em especial, o da indústria, com 124,9 mil novas vagas e o de serviços, com 122 mil, o que responde por cerca de dois terços do total de novos empregos no período citado.

A escolha pelo setor serviço como objeto de estudo justifica-se, dentre outros motivos, por esse crescimento e pela constatação do declínio da divisão clássica entre setor industrial e setor serviço. A cisão tem se mostrado frágil na medida em que a indústria incorpora a noção de serviço no seu modo de funcionamento e, por sua vez, um serviço incorpora tecnologia, organização social, objetivos de eficiência e princípios semelhantes aos desenvolvidos na indústria. Apesar dessa semelhança, existem singularidades relevantes entre um setor e outro e verifica-se a necessidade da adoção de avaliações pluralistas para poder analisar adequadamente o setor serviço. Isso porque os critérios adotados para a avaliação de produtividade devem levar em conta novos fatores e, consequentemente, construir instrumentos de análise mais apropriados. Tendo esse desafio como motivação, e entendendo que a engenharia de produção não pode se furtar a enfrentá-lo, tratou-se aqui de observar de perto duas organizações do setor serviço e propor a utilização de ferramentas de avaliação de produtividade que levem em conta suas singularidades. Selecionou-se então dois grupos desse setor em expansão: o hoteleiro e o de alimentação que, segundo Gadrey (2001), são marcados por uma progressiva participação no emprego no setor terciário.

Sabe-se que o objetivo principal de uma empresa é dar lucros, entretanto, cada um dos negócios estudados, por estarem inseridos em ambientes diferentes, buscam alcançar a lucratividade por meios distintos. No setor serviço, o caminho adequado para atingir esse objetivo é a prestação de serviços com excelência, que se entende como procedimentos que envolvem desde a fidelização de clientes à estratégia escolhida pela empresa para sobreviver com bom desempenho financeiro num ambiente de concorrência. Investigar como as empresas alcançam esse objetivo foi uma primeira intenção do estudo. A segunda foi identificar o lugar atribuído à competência de pessoas, assim como sua gestão, como elemento que pode incrementar o valor ofertado. A abordagem proposta sugere que as competências influenciam na qualidade das empresas, entretanto a noção que se trabalha aqui é a de que a gestão de competências não está restrita às instâncias gerenciais (SCHWARTZ, 2004) sendo exercitada de maneira generalizada pelo sujeito ao trabalhar. As empresas escolhidas, e esse foi um fator decisivo nas escolhas, tem em comum o fato de não atrair clientes pelos preços baixos e sim por investirem em qualidade. Os objetivos de desempenho dos sub-setores hotelaria e alimentação são bastante distintos, afinal tratam-se de negócios em segmentos diferentes, mas por outro lado, podem ser muito similares quando se analisa a preocupação dada à qualidade percebida pelo cliente. Neste aspecto destacam-se dos concorrentes e garantem sua excelência. Devido ao interesse por esse diferencial pretendeu-se compreender as relações que se estabelecem entre os objetivos de desempenho de cada negócio, suas semelhanças e diferenças. Para isso, foi necessário mapear os diferentes conceitos de qualidade que cada agente envolvido no processo de prestação de serviços possui.

A metodologia utilizada no estudo foi a Análise Ergonômica do Trabalho combinada à aplicação de alguns modelos de produtividade. Os modelos não foram utilizados integralmente devido à opção de recorte da pesquisa. O modelo de excelência proposto por Caon e Corrêa (2002) trata de diversos atores envolvidos na criação de um serviço de excelência. Trabalhou-se com alguns deles, tais como: valor ofertado, front office e back office, satisfação dos funcionários e uso adequado dos recursos. 
Outros atores envolvidos não puderam ser priorizados neste momento, como, por exemplo: tecnologia de informação, recursos humanos (RH), parceiros, concorrentes, práticas de preço, custo e estratégia ligadas ao market share. Já o quadro multicritério sugerido por Gadrey (2001) teve todos os seus critérios analisados, contudo, o desenrolar desta abordagem que tem como conseqüência a atribuição de pesos para cada um destes critérios em cada uma das organizações, foi deixada para uma próxima etapa de estudo. Vale ressaltar que o enfoque adotado valoriza a singularidade dos contextos e procura questionar a aplicação cega de modelos. Por esse motivo, na análise dos dois casos selecionados, optou-se, por exemplo, pela flexibilização da matriz proposta por Gadrey (2001). Essa precaução assumida deve-se à preocupação permanente em respeitar as especificidades e, portanto inviabilizar os procedimentos clássicos de generalização de modelos e métodos e sua aplicação mecânica e indiscriminada fazendo com que cada caso seja analisado com suas características específicas. Não se pretende com isso negar os próprios fundamentos da ciência em sua característica de generalização, mas afirmar que a relação dinâmica entre o geral e o particular exige uma postura clínica de análise caso a caso. Nesse sentido, não houve intenção de comparação dos casos estudados e sim do exercício de aplicação de modelos e conceitos (no caso do modelo de excelência, da matriz multicritério, da noção de carga de trabalho, dos ingredientes da competência entre outros) flexibilizando-os, permitindo assim que fossem contempladas as adaptações sempre necessárias aos diferentes contextos. A última, mas não menos importante consideração sobre a metodologia utilizada, alerta para o cuidado na aplicabilidade das ferramentas apresentadas em outras empresas de serviço. Por apresentarem inúmeras particularidades, as ferramentas aqui apresentadas são adequadas apenas às empresas em estudo. Qualquer outra empresa que venha a utilizar essas propostas terá que analisar suas próprias características, objetivos e metas para somente então, pô-las em prática.

Os referenciais teóricos utilizados no estudo foram oriundos de autores que têm se dedicado a investigar o setor serviço com o intuito de tentar identificar suas características e singularidades tanto nos aspectos econômicos (GADREY, 2001; SCHWARTZ, 1992; ZARIFIAN, 2002) quanto nos organizacionais (ZARIFIAN, 2001a; SALERMO, 2001, SLACK et al., 2002; CAON e CORRÊA, 2002) ou nos aspectos especificamente relativos à organização do trabalho (SCHWARTZ, 1992; VIDAL, MUNIZ E ALVAREZ, 2001). Os aspectos comunicacionais e linguageiros (LACOSTE, 1998) também foram determinantes para explorar a riqueza da noção de competência (SCHWARTZ, 1998; ZARIFIAN, 2001b, 2001c).

Inicialmente o texto apresenta duas organizações do setor serviço que têm como principal característica da retenção de clientes a qualidade nos aspectos comunicacionais operacionalizados pelos funcionários. Desenha-se um panorama de cada organização enfatizando a organização do trabalho, os fatores técnicos e os processos. Em seguida, identificou-se as interações entre linha de frente (front office) e retaguarda (back office) buscando interpretar o significado da prestação de serviços para cada uma das organizações (valor ofertado). Posteriormente analisaram-se como as comunicações (internas e externas) e as competências podem influenciar na qualidade das empresas. Por fim, avaliou-se a produtividade em cada uma das empresas estudadas utilizando quadros multicritério.

\section{Estudo de caso I: ramo alimentício}

\subsection{A empresa}

O estudo de caso I foi realizado na filial Cinelândia de uma rede de restaurantes que oferece aos clientes café da manhã, almoço, encomendas para viagem e sanduíches. A empresa, situada no centro do Rio de Janeiro, é considerada um caso de sucesso na prestação de serviços, pois foi fundada há 20 anos e hoje conta com sete estabelecimentos. Sua proposta é oferecer comida saudável com bom atendimento, baseado num sistema de porções.

A produção é artesanal, o que significa que cada loja produz tudo o que vende, com exceção das sobremesas, que são terceirizadas. Devido a sua localização, o restaurante enfrenta uma concorrência bastante acirrada. Atualmente dos cerca de 1.100 atendimentos diários, sendo que 93\% são de clientes 
fiéis, compostos basicamente por pessoas que trabalham nas redondezas e buscam uma opção saborosa e saudável de alimentação, assim como rapidez no atendimento e qualidade nas refeições oferecidas.

\subsection{Organização do trabalho, competências solicitadas e estratégias de treinamento/formação}

Os diretores da empresa percebem a importância do contato direto com os funcionários, fazendo com que isso se torne um diferencial de gestão. Por sua vez, os funcionários percebem de maneira positiva essa interação e sentem-se parte da equipe. Algumas vantagens por eles apontadas são: a possibilidade de crescer na empresa (uma vez que novas lojas são abertas), um clima organizacional favorável e o sistema de rotatividade, onde os trabalhadores são treinados para exercer diferentes funções. Como o quadro funcional é fixo, as lojas que abrem no final de semana utilizam-se de um sistema de escala de funcionários entre as filiais. Aqueles que serão escalados para trabalhar no sábado ou domingo podem folgar durante a semana, nos dias de menor movimento. Esse sistema só é possível, porque os trabalhadores são treinados para exercer diferentes funções.

A atenção às pessoas foi citada como uma das preocupações da empresa. Desde a seleção, a rede possui critérios exigentes tanto para o trabalho de front office quanto para o de back office. A escolaridade mínima exigida é ensino fundamental com exceção dos funcionários mais antigos. Além disso, para o balconista, é preciso que o candidato seja comunicativo, simpático, com boa aparência, atento e que saiba interagir com o público. A funcionária do balcão, por exemplo, deve estar atenta não só aos pedidos de clientes que estão sendo servidos no momento por ela, mas também daqueles que estão na fila e serão atendidos em breve. Dessa forma o trabalho da atendente é semelhante ao de um motorista, que, ao pisar no freio para acompanhar a parada do carro da frente, deve estar atento aos carros que estão atrás.

Os diretores da empresa percebem a importância do contato direto com os funcionários, fazendo com que isso se torne um diferencial de gestão. Os funcionários percebem de maneira positiva essa interação e se sentem parte da equipe, uma vez que todos os diretores conhecem cada funcionário pelo nome. Esta interação traz como benefício o aproveitamento dos funcionários para cargos de maior responsabilidade. Ou seja, os funcionários percebem as chances de crescimento dentro da empresa. Os gerentes consideram o atendimento como principal diferencial, seguido da qualidade dos alimentos e do custo. Para atingir tais objetivos preocupam-se em manter a padronização do sistema de porções que, embora traga certa rigidez ao processo, evita a lentidão no fluxo de pessoas, muito valorizada pela fiel clientela do restaurante.

\begin{tabular}{|l|l|}
\hline \multicolumn{1}{|c|}{ Item } & \multicolumn{1}{c|}{ Descrição } \\
\hline Número de funcionários & $\mathbf{3 5}$ \\
Faixa etária & $\mathbf{1 8}$ a 40 anos \\
Nível de instrução & Ensino médio, com exceção dos mais antigos \\
Benefícios & Vale transporte, alimentação no local com cardápio diferenciado \\
Rotatividade & Baixa \\
Taxa de absenteísmo & Baixa devida ao pacote de benefícios \\
Saúde e segurança & Plano de assistência médica \\
Jornada de trabalho & 8 horas com horário de entrada diferentes \\
Manual de procedimentos & Manual de normas e higiene e mapa das tarefas diárias \\
\hline
\end{tabular}

Figura 1 - Dados gerais sobre os funcionários do restaurante

Para os funcionários da cozinha solicita-se agilidade, atenção, vontade de aprender e aptidão para desempenhar diferentes funções. Segundo o chefe de cozinha, a multifuncionalidade é um ponto a favor do restaurante, pois na ausência de um funcionário, outro assume suas funções. Na ausência de mais de três funcionários, o que é considerado um fator que possibilita a queda na qualidade dos serviços prestados, o próprio chefe de cozinha assume as demais funções. Para facilitar este rodízio elaborou-se um mapa de tarefas com os objetivos de cada funcionário. O chefe de cozinha, por exemplo, é responsável pela manutenção da qualidade, pela coordenação da higienização e, 
principalmente, pela motivação dos funcionários para que eles alcancem a grande agilidade necessária para as funções da cozinha.

Nesse ramo de negócio, o fracasso pode estar relacionado à falta de assepsia do local e dos alimentos. Para manter o padrão de qualidade estabelecido realizam-se avaliações periódicas e treinamentos que abrangem áreas como a higienização do local, dos utensílios e dos alimentos. São enfatizados também os cuidados com recebimento, manuseio, preparo e armazenagem dos alimentos, assim como com a aparência das atendentes e funcionários. Os novos funcionários são treinados a cada dois meses e os mais antigos a cada quatro meses para que os conceitos e normas da empresa sejam bem fixados. $\mathrm{O}$ treinamento é realizado no escritório central com duração de aproximadamente duas horas. As turmas são formadas por funcionários de diferentes filiais com o intuito de promover a troca de experiências, o que leva a melhorias através da padronização dos procedimentos. Nos conteúdos dos treinamentos foram reforçadas as normas de higiene pessoal (manter as unhas sempre bem cortadas, fazer a barba, utilizar toucas, bonés e luvas etc). Para conseguir atingir esse objetivo o restaurante sensibilizou a família de cada funcionário realizando sessões conjuntas de reflexão sobre os atos que poderiam levar a infecções alimentares pela falta de higiene. Questionava-se os funcionários sobre quais passos deveriam ser seguidos ao chegar em casa com as compras do supermercado desde o armazenamento até o consumo. A cada passo, as conseqüências daquele ato eram comentadas, mostrando a rapidez de proliferação de bactérias e fungos em alimentos, latas, caixas de leite, exemplificando com casos reais as conseqüências do descaso com a higiene. $O$ resultado dos treinamentos foi positivo e os conceitos não só foram compreendidos, como também assimilados, fato comprovado pelas mudanças no comportamento dos funcionários no dia-a-dia em suas casas. Os chefes de cozinha e balcão, além dos treinamentos usuais recebem outros diferenciados, que buscam dar formação gerencial, principalmente no que tange à coordenação de pessoas e aos fatores técnicos. Para operacionalizar essa prática a empresa procura selecionar cursos bem conceituados, mesmo ministrados em outras cidades, que são vistos como investimentos.

Há pouco tempo pratica-se uma avaliação de desempenho dos funcionários recém contratados quando completam 30 e 60 dias na empresa. Para os demais funcionários está sendo implementado um plano de avaliação periódica mensal, pois atualmente a avaliação está apenas relacionada ao baixo desempenho. Nesse caso faz-se uma entrevista pessoal com a chefia, seguindo um roteiro que contempla todas as atividades pertinentes a cada função.

Um dos passos necessários para se estabelecer e definir competências é a compreensão da atividade de trabalho realizada. A procura pela identificação dos elementos presentes na carga de trabalho definida por Wisner (1994) como a relação entre as dimensões físicas, psíquicas e cognitivas contribui para essa compreensão. As situações identificadas no restaurante e listadas a seguir estão relacionadas com a carga de trabalho.

- A carga física é requerida no trânsito de materiais e insumos tais como: alimentos, bandejas, travessas e saladeiras entre estoque, cozinha e balcão. As saladeiras, anteriormente muito pesadas por serem de madeira, hoje são de material leve de fácil manuseio. Outro aspecto da carga física é o próprio ambiente da cozinha que é um espaço confinado e sem muita ventilação.

- A dimensão cognitiva é amplamente percebida no trabalho das atendentes devido ao intenso contato com o cliente e às exigências de alta qualidade no atendimento requeridas pela empresa. Faz parte da estratégia de atendimento, um tratamento diferenciado ao cliente que vai pela primeira vez ao restaurante para que os objetivos de gestão de filas sejam atendidos. Dessa forma, a atendente do balcão fica sempre alerta ao cliente que possa estar impedindo o andamento da fila. Este cliente geralmente é aquele que não conhece o serviço prestado pelo restaurante. Nesta situação o procedimento indicado pela gerência é que a atendente saia de trás do balcão, retire o cliente da fila e dê a ele uma atenção especial, explicando como o restaurante funciona e quais são os pratos que estão sendo servidos. Assim, o cliente fica à vontade para fazer sua escolha sem sentir-se pressionado. Por isso, os funcionários que 
exercem atividades de front office devem ser profissionais capazes de tomar decisões, de entender a importância do fluxo durante todo o processo da prestação do serviço e de antever possíveis problemas. A dimensão cognitiva é solicitada principalmente nesse aspecto, mas também é demandada pela linguagem específica presente tanto no trabalho das atendentes como no dos funcionários da cozinha, assim memorizar o nome das saladas e sua composição, os termos relacionados à culinária, aos utensílios de trabalho e à própria organização são conhecimentos necessários para o cumprimento das tarefas.

- Por último, a dimensão psíquica se faz presente na supervisão, principalmente no trabalho das atendentes, que são constantemente analisadas e controladas. Segundo a chefa de balcão, o sorriso deve ser espontâneo. Essa necessidade se torna uma exigência desumana já que não é possível obrigar as pessoas a estarem felizes a todo o momento. Na cozinha a pressão, mesmo mais amena, ocorre no momento em que o chefe experimenta os pratos preparados, pois sempre há grande expectativa quanto à sua aprovação. Entretanto, os funcionários dizem ser essa pressão mais suportável. Essa pode ser uma das causas para que a rotatividade no balcão seja maior do que a da cozinha.

\subsection{Dimensão técnica e organizacional}

O restaurante funciona com um sistema peculiar de porções representado por um diagrama de saladas que define o posicionamento e o tamanho destas porções no prato. O sistema de porções de saladas é rígido e inflexível. Cada porção representa exatamente um tipo de salada escolhida, que não pode ser dividida em dois ou mais tipos. Ou seja, não existem "porções caprichadas" e o cliente não pode solicitar uma porção menor de um tipo de salada apenas para experimentar. Existem alguns motivos para tal inflexibilidade. Por exemplo, no momento que é emitida a comanda, o comandeiro faz uma avaliação visual do prato que, caso não corresponda a nenhum dos diagramas, ficará fora do padrão de preços. Outro motivo de não abrir exceções é pelo apreço em manter a padronização, que evita a lentidão no fluxo de pessoas, muito valorizada pela clientela que freqüenta o restaurante na certeza de um pronto atendimento.

Em muitos casos, o cliente já chega ao local sabendo exatamente o que irá consumir, pois o restaurante disponibiliza seu menu pela Internet e por panfletos em dispensers no balcão. Às vezes, os consumidores chegam a telefonar e até mesmo enviar um portador da empresa para saber previamente o cardápio. Segundo dados da gerência, o cliente permanece em média trinta minutos dentro da loja, o que inclui o tempo de espera na fila, o tempo do consumo e o tempo da fila de pagamento. O tempo de espera na fila é contado desde o momento em que o cliente entra no restaurante até que sua comanda seja gerada, o que acontece no máximo em 4 minutos. O tempo de refeição é de cerca de 20 minutos, um tempo relativamente pequeno pelo fato da maioria dos clientes não permanecer nas mesas conversando após a refeição. O pagamento pode ser considerado um gargalo dentro do processo porque, aos olhos dos clientes, este é um tempo que não agrega valor ao serviço, ou seja, a tolerância do cliente a este tempo de espera é ínfima. Portanto, ele deve ser reduzido ao máximo e hoje gira em torno de 5 minutos, chegando, em seu horário de pico, a 10 minutos ou mais. A preocupação com o fluxo de pessoas em cada etapa dentro do restaurante é vital para a percepção de qualidade do cliente.

Outra vantagem decorrente da padronização dos pratos e do cardápio diário oferecido em todas as lojas é a confiabilidade gerada em seus consumidores. Esta característica possibilita que o cliente possa encomendar sua refeição sabendo exatamente o que irá comer, sem que para isso, tome sua decisão baseada na aparência das refeições expostas no balcão. Além disto, a composição da salada é também objeto de preocupação. Como a maioria dos clientes conhece bem os pratos servidos, caso falte algum ingrediente para sua composição, ele não será servido, pois o sabor final do prato estaria comprometido.

Ao chegar ao restaurante, o cliente encontra três opções de fluxo para seguir: sanduíche, viagem e restaurante. A produção da refeição é dimensionada de acordo com a demanda. Nenhuma parte da elaboração dos pratos é feita na véspera. Todos os alimentos são preparados e consumidos no mesmo 
dia. Há em média três produções diárias de saladas: o primeiro balcão é montado às 11 horas, quando ocorre o início do almoço e o segundo balcão é reposto por volta das 13 horas; às 14 horas as necessidades são checadas e uma nova produção é feita de acordo com elas; a partir das 15 horas são produzidas apenas em pequenas quantidades as saladas tradicionais mais consumidas e as outras opções de pratos são reduzidas à quantidade remanescente que está no balcão. Segundo informação da nutricionista, o restaurante recebe durante o dia um público equivalente a oito vezes a sua capacidade de assentos, o que demonstra a necessidade de uma estrutura que tenha uma grande interação entre todas as partes envolvidas agilizando o atendimento.

A preocupação com a qualidade dos alimentos é essencial para a sobrevivência do restaurante. A qualidade pode ser garantida pela submissão dos pratos à aprovação do chefe de cozinha antes de serem servidos. Outra maneira de garanti-la é a utilização de insumos básicos de alta qualidade: azeite do tipo extra virgem para o tempero das saladas e gelo filtrado para gelar as bebidas, são exemplos dessa opção.

Para atender a clientela, não basta uma comida de qualidade, é necessário principalmente um atendimento que supere as expectativas. Verificou-se que os gerentes percebem como principais prioridades na gestão do restaurante em primeiro lugar o atendimento, seguido da qualidade dos alimentos e do custo. Por trabalharem com um sistema de porções, onde a margem de lucro de cada porção é variável, a preocupação com as despesas é amenizada, porque o custo de cada tipo de alimento acaba se equilibrando. Por exemplo, uma porção de filet mignon, cujo quilo custa $\mathrm{R} \$ 19,00$, pode apresentar uma margem negativa que, no entanto se dilui quando comparada à porção de arroz que, por custar centavos, tem uma margem de lucro muito significativa. O sistema de porções pode ser muito vantajoso para a empresa, pois assegura uma receita mínima. Hoje, esta receita gira em torno de $\mathrm{R} \$ 10,00$ por refeição, para a maioria dos clientes.

Uma conseqüência da estratégia de priorização da qualidade do produto e das atividades de front office pode ser verificada pelo baixo número de reclamações, mesmo tendo à disposição dos clientes diversos canais para este fim (Internet, presença do gerente e nutricionista na loja). Quando ocorre algum tipo de reclamação, o cliente é convidado a conhecer a cozinha e também lhe é oferecida uma cortesia.

\section{Cargos de apoio ao balcão e cozinha}

\section{Caixa}

Responsável por inserir o número da comanda no sistema e, receber o pagamento.

\section{Comandeiro}

Encarregado de formular o preço dareife içao e entregar ao cliente a comanda.

\section{Compras}

O setor de compras é único para todas as filiais e tem interação direta com as lojas. $O$

planejamento de pedidos é feito pela nutricionista tendo como base o inventário diário da

loja. A periodicidade dos pedidos entregues para as lojas pode ser dividida em basica mente três tipos: os quinze nais, de estocáveis; os semanais, de laticínios e carnes e os diários, de frutas, verduras e legumes.

\section{Informática}

Responsável em manter os sistemas informatizados de controle de estoque, comandas e pagamentos.

\section{Recrsos humanos}

Encarregado pela seleçao, treinamento, avaliação de desempenho, gerenciamento da motivação do clima organizacional.

Figura 2 - Cargos de apoio ao balcão e cozinha 


\section{Estudo de caso II: setor de governança do ramo hoteleiro}

\subsection{A empresa}

O estudo foi realizado num estabelecimento de luxo de hotelaria internacional cinco estrelas, localizado na praia de Copacabana, Rio de Janeiro, atuando no Brasil desde 1990. De origem francesa e localizado em meio à grande concorrência, o hotel recebeu inúmeros prêmios pelo seu destaque no ramo e conquistou certificações de qualidade. A rede totaliza seis unidades e objetiva alcançar 10 até o final de 2005.

O hotel oferece hospedagem, restaurantes com serviços variados, salões para congressos, eventos sociais, área de lazer, coquetéis, babysitter, banquetes e um centro de negócios. Sua clientela é composta de executivos a negócio e turistas a lazer vindos da Europa e das Américas. Há ainda tratamento diferenciado para VIP's (cliente assíduo ou pessoa pública), apartamentos com diferentes graus de requinte e necessidades (deficientes físicos e serviços próprios de cuidados com a saúde).

\subsection{Organização do trabalho, competências solicitadas e estratégias de treinamento/formação}

A gerência considera fundamental fornecer serviços de qualidade, o que é traduzido como atender bem, oferecer um ambiente agradável e o máximo de conforto. Seus funcionários devem ser hábeis para dispor de pronto atendimento às solicitações dos hóspedes. Uma característica valorizada pela clientela é o tratamento personalizado, o que impulsiona a flexibilidade possibilitando o atendimento a diferentes grupos (famílias, executivos, etc). Em contrapartida, o custo não é um critério levado em consideração pelos hóspedes.

O enfoque do estudo deu-se no trabalho dos camareiros por entender que essa é uma categoria profissional que acumula a um só tempo atividades de front e back office. O programa de treinamento realizado na primeira semana para os recém contratados consiste em um aumento gradativo da carga de trabalho (de 12 a 18 quartos). Um funcionário especializado e experiente acompanha o novato e mostra as tarefas e o padrão de qualidade mínimo exigido pelo hotel. Nestes dias ocorre a familiarização do funcionário com os demais cargos, a linguagem técnica utilizada, o clima organizacional e as dimensões física, cognitiva e psíquica da carga de trabalho. Alguns procedimentos de arrumação são padronizados como o posicionamento de móveis, bandejas, bloco de anotações, questionário de satisfação, a forma da dobradura do lençol e do papel higiênico. Apesar da importância do trabalho dos camareiros(as) na percepção de qualidade do hóspede, poucos recursos são disponibilizados em treinamentos e ações que aprimorem o resultado do trabalho, como, por exemplo, o incentivo à comunicação.

\begin{tabular}{|l|l|}
\multicolumn{1}{|c|}{ Item } & \multicolumn{1}{c|}{ Descrição } \\
\hline Número de funcionários & 400 (23 camareiros) \\
Faixa etária & 30 a 50 anos \\
Nível de instrução & Ensino fundamental completo e cursos profissionalizantes \\
Rotatividade & Quase nula \\
Taxa de absenteísmo & Foi reduzido devido a diminuição de quartos por jornada \\
Saúde e segurança & Serviço médico, enfermagem e CIPA \\
Jornada de trabalho & 4 turnos de 8 horas \\
Manual de procedimentos & Não há manual de processos e posturas \\
\hline
\end{tabular}

Figura 3 - Dados sobre a população dos camareiros(as)

Outros fatores que devem ser considerados na organização do trabalho e que contribuem para a demanda e solicitação de competências são as dimensões físicas, cognitivas e psíquicas que compõem a carga de trabalho (Wisner, 1994). 
Quando o camareiro(a) arruma o quarto, força muscular significativa é requerida em diversos momentos como para forrar a cama (devido ao peso do colchão e do cobre-leito), armazenar a roupa suja, ou ainda na limpeza da banheira. Há também intensa solicitação corporal, pois os funcionários têm posturas inadequadas na execução das tarefas.

Os aspectos cognitivos são requisitados na memorização de posições dos móveis, temperatura do quarto e utilização de dispositivos técnicos. Os camareiros(as) memorizam uma série de regras que devem ser seguidas na arrumação dos quartos, como mostra A figura abaixo.

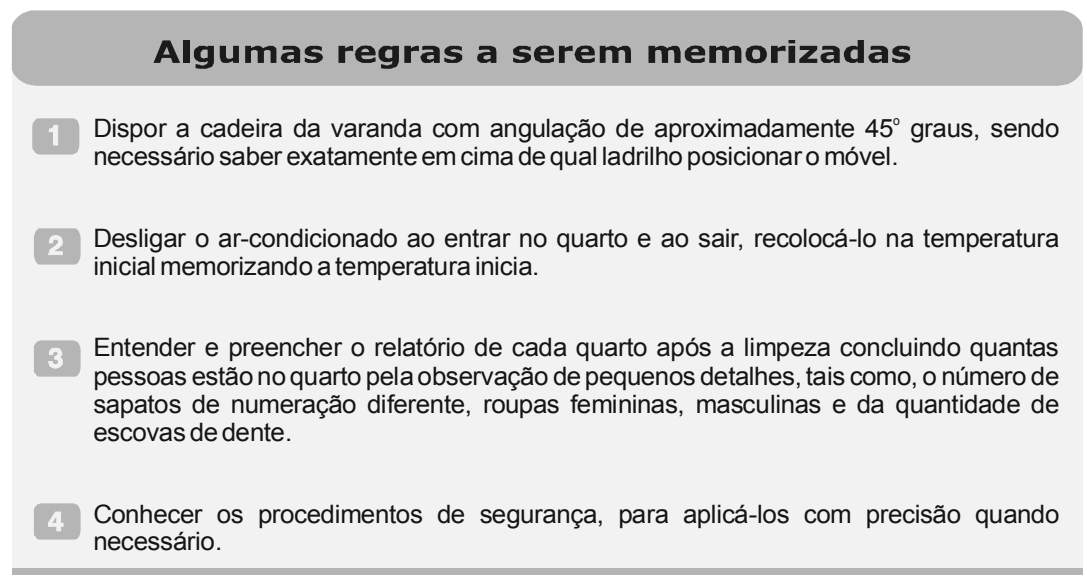

Figura 4 - Regras de memorização para os camareiros(as)

Outro fator que solicita a dimensão cognitiva é o aprendizado das expressões de linguagem utilizadas pelos camareiros(as) na comunicação interna, tais como: "order taker", "turn down", "abertura de mesa" que devem ser rapidamente incorporadas ao vocabulário dos trabalhadores. Além disso, devem estar atentos aos detalhes que denotam a singularidade de cada quarto como a definição do número de amenities segundo a categoria do cliente, a prioridade de limpeza dos quartos de hóspedes que estão de saída etc. $\mathrm{O}$ uso de bips também pode ser considerado como um fator a mais do componente cognitivo da carga de trabalho. Aprender a manusear o bip é uma tarefa extra e exige raciocínio para seguir o passo-a-passo do processo.

Quanto à dimensão psíquica percebe-se que os camareiros(as) sentem-se muito pressionados já que são sempre controlados. Como exemplo disto pode-se citar o uso de bips (acima citado) e o fato de haver uma supervisão permanente do trabalho realizado, gerando uma sensação de desconforto em estar constantemente sujeito à aprovação de seus supervisores. Outro aspecto desta dimensão está ligado ao convívio com a intimidade, às exigências e ao sentimento de desconfiança dos hóspedes. Quando limpam os quartos, os camareiros (as) entram, inevitavelmente, na intimidade dos hóspedes, pois para arrumar o quarto manuseiam objetos pessoais e limpam as "sujeiras" das pessoas. Isso pode levar a situações constrangedoras e embaraçosas. O clima de desconfiança é uma constante no ambiente devido aos objetos de valor que ficam nos quartos. Para tentar impedir qualquer iniciativa de furto, as bolsas pessoais dos funcionários são verificadas ao final do expediente.

A análise da atividade constatou que muitos fatores que incidem sobre as dimensões cognitiva e psíquica poderiam ser minimizados, ou até mesmo eliminados, com o incentivo à comunicação. Apontou também para a sugestão da implantação de um programa de treinamento "on the job". Esta capacitação incluiria, além da orientação postural voltada para a atividade, o significado dos termos técnicos usados na Governança, o uso do bip e outros equipamentos, a elucidação dos componentes químicos dos produtos manipulados e de seus possíveis riscos para a saúde. 


\subsection{Dimensão técnica e organizacional}

Na rotina de trabalho da camareira, existem dois tipos de arrumação de quarto: no turno da manhã, arrumação e limpeza; no turno da tarde, "turn-down" ou "abertura de cama", que consiste em conservar o trabalho feito no primeiro turno, preparando o quarto de maneira aconchegante para a chegada do hóspede ao fim do dia. Para realizar a organização dos quartos, os equipamentos principais são: o aspirador de pó e o carrinho, que contém o material a ser utilizado como toalhas, material de limpeza, amenities etc.

Alguns procedimentos de arrumação são padronizados como o posicionamento de móveis, bandejas, bloco de anotações, questionário de satisfação e a forma da dobradura do lençol e do papel higiênico. Desta maneira, as tarefas são cumpridas e os modos operatórios variam bastante. Alguns realizam as tarefas com capricho extremamente rigoroso enquanto outros com mais rapidez, dependendo do estilo de cada camareiro(a) e também da coordenação do andar. Nem todas as tarefas são realizadas todos os dias, variação que se deve ao movimento do hotel. Entretanto, não existe um critério que explique claramente o que deve ou não ser feito. O estado de "sujeira" de cada quarto também é variável em cada jornada.

O sistema gerencial atual dá uma pontuação para cada quarto de acordo com sua situação de ocupação. Anteriormente, os quartos eram divididos entre as camareiras por ala do hotel, sem levar em consideração a intensidade da limpeza. Este método fazia com que alguns trabalhadores ficassem com uma carga de trabalho muito elevada. Atualmente, a divisão é feita de forma igualitária de acordo com o somatório de pontos: quartos que exigem um trabalho mais intenso recebem uma pontuação maior.

Cada camareiro(a) recebe um relatório com uma listagem dos quartos a serem limpos e encaminha-se ao andar pré-determinado para pegar seu carrinho no almoxarifado, que já foi preparado ao fim do dia anterior. Não existe uma ordem pré-estabelecida a seguir, porém os quartos reservados e os VIPs têm prioridade na ordem da limpeza. No início do dia este relatório funciona como guia do trabalho a ser realizado no turno, e no final do expediente, como relatório do andamento do trabalho do funcionário, pois nele consta o horário de entrada e saída do camareiro(a) do quarto. Existem outros funcionários em diferentes setores que dão apoio ao trabalho dos camareiros (as).

\section{Cargos de apoio ao trabalho dos camareiros}

\section{Coordenadora}

Encarregada de um processo denominado "Discrepância" (controle de qualidade para verificar se as informações que constam nos computadores da recepção representam a realidade dos quartos).

Observa falhas no apartamento referentes à limpeza conferindo e avalia o trabalho do camareiro(a) e o funcionamento dos equipamentos. Auxilia a "order taker" na abertura de mesa.

\section{Arrumadores}

Responsáveis pela limpeza e arrumação dos corredores, dão suporte às camareiras repondo roupa de banho e cama dos carrinhos.

\section{Order Taker} Responsável pelo processo conhecido como "abertura de mesa". Este processo consiste em programar o trabalho de cada camareira, distribuíndo os quartos a serem limpos com ordem de prioridade de arrumação.

Mini-bar

Repõe o estoque de bebidas nos carrinhos da camareira e recolhe as notas dos produtos consumidos para baixa na recepção.

Valet Recolhe o saco de roupas sujas e encaminha para a lavanderia(serviço terceirizado).

Figura 5 - Cargos de apoio aos camareiros(as) 


\section{Considerações sobre o setor serviços e análise crítica das situações estudadas}

\subsection{Modelo de serviços}

A partir da definição inicial de Hill (1977), que descreve a relação social de serviço como sendo uma operação de "mudança de condição", Gadrey (2001) sinaliza que ela é mais adequada aos serviços associados a pedidos de ajuda ou "reparação", de conservação, de assistência intelectual ou material, etc., mas não a serviços, como hotelaria, alimentação, entretenimento e turismo nos quais se percebe menos o que pode representar "a mudança na condição de uma pessoa ou de um bem pertencente a um agente econômico". O segundo autor parte então para demarcar as singularidades do setor serviços e identificar os fatores de qualidade nele característicos propondo possíveis critérios para estabelecer modelos de avaliação de produtividade.

Zarifian $(2001,2002)$ desdobra a definição de Hill diferenciando-a para serviços e valor de serviço. Dessa forma, vê os primeiros como acompanhamento de um produto (serviços de pós-venda, serviços de publicidade etc), ou como uma taxa de serviço, que privilegia os compromissos assumidos com o cliente (reparação e conformidade do produto com suas especificações de qualidade). $\mathrm{O}$ valor de serviço é interpretado com uma abordagem a partir das conseqüências e outra a partir dos recursos que são mobilizados para se atingir os resultados que se queiram. Centra então seus estudos nessa última abordagem propondo a criação de um "modelo de serviços" que englobaria três universos distintos: o da concepção de novos produtos ou serviços, que reúne as atividades de pesquisa e desenvolvimento e marketing; o dos grandes sistemas técnico-administrativos, responsável pelos processos e garantia de bom atendimento e, finalmente, o universo da relação direta com os clientes ou usuários.

Schwartz (1992), Zarifian (2001) e Vidal, Muniz e Alvarez (2001) concordam que existe atualmente uma convergência entre o setor industrial e o setor de serviços, pois os limites entre um e outro são tênues na medida em que, a indústria incorpora a noção de serviço no seu modo de funcionamento e, por sua vez, um serviço incorpora tecnologias, organização social, objetivos de eficiência e princípios semelhantes aos desenvolvidos na indústria. Enfatizam, entretanto, que as duas lógicas (setor industrial e setor de serviços) possuem origem diferente e conseqüentemente, há relação problemática entre elas.

Caon e Corrêa (2002) fazem uma análise entre produtos e serviços com o objetivo de encontrar pontos convergentes e divergentes destas duas naturezas de operação já que cada vez mais as empresas se vêem obrigadas a oferecer um pacote de valor aos seus clientes, composto de uma parcela de produtos e outra de serviços, o que implica que as operações devem gerenciar ambas as partes. Os autores discutem três características que poderiam diferenciar produtos e serviços no que tange à analogia com a origem das operações (grau de estocabilidade dos elementos do pacote de valor oferecido; grau de intensidade e extensão da interação no contato com o cliente; grau de percepção da qualidade e do valor do pacote ofertado) e concluem que cada negócio necessitará de técnicas e abordagens diferentes para a gestão da qualidade e avaliação de desempenho do pacote oferecido.

Os mesmos autores evoluem ainda com o conceito de customização em massa mostrando as características dessa forma de produção atual. São serviços que se encontram numa posição próxima à posição de volume dos serviços em massa, mas que, fazendo uso de tecnologias, criam no cliente uma sensação de serviço personalizado quanto à necessidade e percepção de qualidade. Contribuindo para esse debate, Slack (1996) apresenta uma definição de objetivos de desempenho, necessária para que as empresas definam quais características de seu negócio devem ser enfatizadas a fim de melhor atender às necessidades de seus consumidores. Definir os objetivos de desempenho de uma organização, permite a estruturação de estratégias guiando a atuação no mercado. Para o autor, a melhor maneira de se classificar os objetivos de desempenho de uma organização é através de seus stakeholders, que são as pessoas ou grupos de pessoas que, de alguma maneira, possuem interesse na empresa. Estabelece então cinco objetivos de desempenho mais amplos em nível operacional que devem ser priorizados para satisfazer seus stakeholders: qualidade, rapidez, flexibilidade, confiabilidade e custo. 
Schwartz (1995, 1998, 1999); Vidal, Muniz e Alvarez (2001); Alvarez, Erbisti, Bomfim e Rocha (2003), discorrem sobre os aspectos relacionais no trabalho e sobre os ingredientes das competências, discussão também presente no modelo proposto por Zarifian (2002) que aborda a problemática da gestão de competências (individuais e organizacionais) e também os aspectos comunicacionais da empresa na tentativa de atendimento a qualidade. Para entender a comunicação no trabalho e os aspectos referentes à declinação da linguagem os estudos de Lacoste (1998) foram considerados.

Quando o setor de serviços se direciona para o atendimento, novos desafios se apresentam. Nesse sentido é necessário diferenciar as atividades de front office e back office pois elas são de natureza distinta. $\mathrm{O}$ fator determinante da diferença está relacionado à presença do cliente, que traz à atividade de linha de frente um grau acentuado de incerteza e variabilidade. Já as atividades de retaguarda, uma vez realizadas sem a presença do cliente, podem se beneficiar da similaridade com as operações fabris tradicionais utilizando inúmeros métodos e ferramentas de controle e padronização para atingir qualidade e eficiência. O deslocamento do foco da empresa em direção ao front office traz a preocupação em como atender ao cliente, o que nos remete às questões comunicacionais anteriormente citadas nos obriga a entender outros componentes aí presentes. A gestão da demanda, ou seja, a compreensão de seu funcionamento e as possíveis ações sobre ela, seguida da gestão da capacidade produtiva e da administração de filas, apresentam-se, então como fatores estratégicos relevantes. Essa tentativa de gestão faz pensar nos possíveis instrumentos de medida de produtividade e de estabelecimento de modelos de excelência, tais como, o balanced score card e a avaliação multicritério. Para essas análises, as propostas apresentadas por Caon e Corrêa (2002), Gadrey (2001) e Slack (1996) mostram-se pertinentes.

O primeiro desafio a ser enfrentado para entender empresas de serviços está na definição do seu produto, uma vez que várias definições são admissíveis e nenhuma se impõe naturalmente, o que se deve à fraca padronização dos processos, tanto da própria prestação dos serviços quanto dos resultados. No segmento de hotelaria de luxo, a prestação de serviços se dá não somente pela oferta de um leito para pernoite, mas principalmente, pela transformação das condições de atividade do hóspede, em hospitalidade e conforto. No segmento de restaurantes, uma visão limitada da prestação de serviços é interpretada como a satisfação da necessidade do ser humano em alimentar-se. A verdadeira preocupação, no contexto estudado é prover os clientes com uma alimentação saudável e saborosa com a agilidade de uma lanchonete fast-food.

Zarifian (2002) propõe o modelo de serviços representado por três universos distintos. São eles: o da concepção de novos produtos ou serviços, o dos sistemas técnico-administrativos e o da relação direta com os clientes.

Ao aplicarmos essa classificação ao hotel, o primeiro universo destaca-se pela excessiva diversidade de serviços para atender e surpreender os diferentes tipos de clientes que nele se hospedam. A empresa conhece sua clientela e forma um pacote de valor que atenda a necessidade de cada grupo, pois sabe estar vendendo um produto imaterial que é o conforto. Já a proposta do restaurante é atender bem a seus clientes e não adaptar toda a sua estrutura para conquistar outros perfis. A concepção de novos produtos foi criativa ao estabelecer um inovador sistema de porções, a opção de sanduíches, café da manhã e sistema de embalagens para viagem.

O segundo universo se constitui na infra-estrutura técnico-administrativa responsável pelos processos e por prover aos funcionários de linha de frente uma estrutura que lhes permita oferecer um serviço de qualidade. Este universo é fundamental nos dois casos. $\mathrm{O}$ ambiente de serviços, propício a muitas variabilidades, precisa de um gerenciamento que tenha um razoável controle desse universo. As atividades de back office, que são mais facilmente padronizadas, aí se incluem. No hotel, esse universo abrange desde a rede de controle da ocupação dos quartos à escala de trabalho dos funcionários. No restaurante, compreende tanto o controle de estoques via web, como as comandas informatizadas e a cozinha. 
Por último, identifica-se o universo do front-office que se constitui daqueles que têm uma relação direta com os clientes como os atendentes do restaurante, as recepcionistas, telefonistas e camareiras no hotel. Uma característica a ser analisada no terceiro universo é a relação entre o tempo de contato e o grau de interação com cliente, conforme proposto por Caon e Correa (2002). Nos dois casos estudados existe uma intensa interação com o cliente. Percebe-se a complexidade desse universo quando se constata que a percepção de um problema varia muito de pessoa para pessoa. Entretanto, no setor serviços uma interpretação próxima às reais necessidades do cliente é essencial para a sobrevivência do negócio. Nesse universo as competências dos funcionários configuram-se no fator qualidade exercido na atividade. Deve-se então considerar as distinções regionais, sociais, étnicas e culturais que diferenciam cliente (hóspede ou consumidor) do prestador de serviço (atendente, balconista ou camareiro), para perceber a importância da formação e da colocação em prática de competências diversas como instrumento capaz de adequar a visão dos funcionários à dos clientes.

\subsection{Influência da comunicação interna e externa na geração de valor}

Para que se compreendam as representações e os anseios das pessoas envolvidas numa determinada situação de trabalho é preciso criar meios que permitam que as comunicações internas e externas sejam estabelecidas. Para isto, antes de tudo, é preciso compreender o seu principal componente: a linguagem.

A linguagem descreve a ação e tem o poder de decodificar o conhecimento, o pensamento, o desejo e as emoções, de marcar as relações temporais, de metaforizar, de prenunciar o futuro, dentre outras características. Ou seja, ela possui vários recursos que permitem elaborar o universo de ação gerando diversas interpretações.

Uma outra abordagem importante em relação à comunicação e à linguagem é como elas se desenvolvem dentro do ambiente de trabalho entre os diversos funcionários e cargos, no contexto da ação. O significado de cada fala produzida depende de diversos fatores - temporais, qualitativos e cognitivos - que envolvem as pessoas que participam de determinada ação. É necessária a compreensão da atividade e suas interações com as pessoas para se entender o verdadeiro sentido de cada fala.

Outro aspecto importante que deve ser valorizado e contribui para criar alternativas de gestão é o incentivo à comunicação das diferentes linguagens que estão em curso nas situações de trabalho, que segundo Lacoste (1998), são: linguagem no trabalho, linguagem como trabalho e linguagem sobre o trabalho. Todas devem ser valorizadas para que se possam minimizar problemas de interação e de desconhecimento sobre o trabalho.

No caso 2 verificou-se que a linguagem no trabalho não é muito desenvolvida pelo grupo, já que a estrutura organizacional não incentiva a interação entre os camareiros (as). Ela ocorre principalmente no horário de almoço e nos encontros pelos corredores do hotel. Entretanto a densidade do trabalho faz com que muitos funcionários não utilizem a hora do almoço como um período de relaxamento e descontração e sim como um horário para cumprir suas tarefas, não fazendo uso da fala não funcional.

Assim, essas falas não são incentivadas, fazendo com que a construção da cooperação seja prejudicada. O mesmo não ocorre no restaurante onde os funcionários trabalham lado a lado, o que cria um intenso relacionamento pessoal. Esse relacionamento é incentivado pela própria gerência. Além disso, a necessidade da consciência com a higienização, que só foi possível por intermédio da convivência familiar, aproximou ainda mais os funcionários.

A linguagem como trabalho no hotel, se dá durante o trabalho diário, quando as camareiras(os), por exemplo, utilizam vários termos técnicos de línguas estrangeiras, em virtude do hotel pertencer a uma rede internacional. Isto provoca um choque de culturas, já que os funcionários contratados possuem baixo grau de instrução. Os termos técnicos são essenciais para a realização do trabalho, pois é por intermédio deles que existe uma compreensão das tarefas a serem cumpridas. Assim, é importante 
destacar o relacionamento interno dos camareiros com os demais cargos do setor da governança, sob a ótica da cultura organizacional, do contato, da comunicação e da linguagem desenvolvidas no contexto da ação e seus diversos componentes. Essa linguagem, no restaurante, se faz presente por meio do entendimento dos pratos oferecidos e todo um vocabulário técnico aplicado nas práticas da cozinha, principalmente.

Por falta de estímulo da organização, a linguagem sobre o trabalho quase não é utilizada no hotel. Não existe nenhuma atividade programada que estimule os funcionários a falar sobre o que pensam do trabalho e a chegar a um consenso sobre as melhores práticas a serem utilizadas. O hotel falha por não incentivar o uso adequado dessa linguagem. Por outro lado, no restaurante, esse tipo de linguagem, não só é utilizada, como incentivada pela gerência via treinamentos com funcionários de diferentes filiais justamente para estimular a troca de experiências, de modos operatórios e a compreensão das diferentes dificuldades.

A comunicação pode ser vista na construção da ação em contextos particulares. Nenhuma ação pode ser aplicada sem sofrer variações e adaptações às ocasiões distintas em que surgem. As variações contextuais e as exigências rotineiras são determinantes na atualização constante das tarefas a fim de regular as variabilidades que ocorrem. O objetivo então é remediar os disfuncionamentos e gerenciar a improvisação, promovendo a modificação da ação e estimulando a tomada de decisões. Entretanto, em alguns momentos, a organização e a ação se chocam em função da rígida hierarquia existente que acaba criando barreiras ao desenvolvimento e crescimento das pessoas envolvidas. Por isto, no setor serviço, os funcionários devem compreender os valores, as atitudes, os objetivos, as estratégias de forma a executar o trabalho e atuar sobre quaisquer variações que venham a surgir de acordo com a cultura organizacional da empresa. Por outro lado a organização também deve permitir isto através de uma cultura que possua como características a estabilidade e flexibilidade. Entra em jogo aí, de maneira pregnante, a gestão de competências.

No caso 2 estudado, esta primeira característica da ação é percebida pelo camareiro(a) desde o início de seu contato com o serviço. A interação inicial do camareiro(a) com o cargo se dá nos primeiros dias de trabalho quando ocorre o treinamento com uma pessoa experiente que lhe transmite as tarefas e o modo como elas são executadas. Após esta fase, o funcionário executa as tarefas sem interferência de ninguém. Percebe então, que cada um as realiza a sua maneira, fazendo adaptações próprias. Os diversos componentes socioculturais se misturam de tal maneira no ato da execução da atividade que interferem no sentido dado à ação e permitem a percepção de que o modo operatório que lhe fora ensinado no treinamento dificilmente será posto em prática da mesma maneira. Contudo, os atendentes do restaurante já não têm tal liberdade para adaptar os modos operatórios. A necessidade do trabalho em equipe e a constante supervisão levam a necessidade de uma maior padronização do serviço. Finalmente, essa padronização faz com que a construção da ação em contextos particulares não seja tão evidenciada no ambiente do restaurante.

Uma outra característica da ação que está na essência de sua construção é a cooperação. No trabalho, os recursos, os conhecimentos e o tempo são divididos de tal maneira que somente o comprometimento individual integrado à cooperação é capaz de permitir o alcance dos objetivos da organização como um todo. Apesar do trabalho de camareiros(as) ser uma atividade com características individuais, o relacionamento e integração com os demais cargos como arrumador, mini-bar, valet e coordenadora são essenciais para o desenvolvimento da ação. No restaurante, o trabalho das atendentes e cozinheiros funciona de maneira análoga, pois igualmente possui características individuais, mas prioriza o trabalho em equipe. Neste tipo de situação a linguagem como trabalho é a principal ferramenta. Para isto, entretanto, um certo esforço cognitivo e psíquico é exigido. Para aumentar a eficiência, eles devem estar em sintonia e a comunicação deve ser efetiva, de maneira a agilizar o processo.

Uma última característica da ação, necessária para gerenciar imprevistos, é a constante coordenação, controle e avaliação. No hotel a arrumação é controlada por supervisoras que estão continuamente avaliando o resultado do trabalho dos camareiros a fim de manter o padrão de qualidade sustentado 
pelo hotel na limpeza dos quartos. Entretanto, a execução da tarefa é feita sem nenhuma supervisão ou procedimento definido. Cada camareiro executa as tarefas da sua maneira de forma a alcançar os mesmos objetivos. Neste contexto devemos levar em consideração diversos aspectos intrínsecos como a idade, a capacidade física, agilidade, capricho, modo operatório, entre outros. Não existe nenhuma instrução que faça com que estes fatores interajam e atinjam patamares satisfatórios. A coordenação, controle e avaliação no estudo de caso 1 é muito mais presente, pois o controle é exercido durante a prestação do serviço e não após sua execução como é o caso do hotel. Ou seja, acontecem simultaneamente, trazendo ao funcionário uma forte carga psíquica uma vez que todos os seus atos estão sendo avaliados.

Num hotel a comunicação com conceptores, produtores e comerciantes precisa acontecer em tempo real de forma a resolver os problemas que surgem. Necessita-se então de uma estrutura bem definida e organizada que seja capaz de administrar os contratempos. Pode-se analisar a importância da comunicação quando um hóspede se queixa de algum problema no seu quarto a um camareiro(a). Essa informação precisa chegar aos gestores do hotel para que esses possam resolver o problema. Para que a comunicação seja eficiente, a camareira(o) precisa saber exatamente a importância do problema ocorrido e como proceder, concebendo a queixa como problema. Esta etapa parece de fácil realização, entretanto, quando se consideram as diferenças regionais, sociais, étnicas e culturais que diferenciam o hóspede do camareiro percebe-se a complexidade da questão.

A percepção de um problema pode variar muito de pessoa para pessoa, pois o que é um grande problema para um pode não significar nada para o outro. E é exatamente essa dúbia interpretação que deve ser evitada no universo dos serviços, onde uma interpretação exata das reais necessidades do cliente é essencial para a sobrevivência do negócio. Outra questão associada à comunicação da camareira(o) com o hotel consiste na habilidade dela em resolver situações adversas em tempo hábil, pois o diferencial na prestação de serviços se dará justamente pela habilidade de seus funcionários em contornar situações. Trata-se então, de focar a demanda por competências específicas.

\subsection{Gestão das competências e percepção da qualidade na geração de valor}

Zarifian (2002) caracteriza o "modelo de competência" no universo de serviços considerando a competência como a iniciativa de um indivíduo sobre uma situação e a responsabilidade sobre os efeitos dessa iniciativa. Por isso, a competência é mais solicitada em situações de incerteza e surpresa. O exercício da competência solicita uma inteligência prática da situação que mobiliza os conhecimentos adquiridos, a compreensão da singularidade desta situação e a atitude adequada tomada.

Schwartz (1999:79; 1995:246) vai adiante e afirma que, em situação de trabalho, há construção de compromisso que se dá pela "colocação de patrimônios": alguma coisa na ordem dos saberes e dos valores, fundamental para compreender a vida das empresas, os ambientes e locais de trabalho. Há então uma alquimia, que estabelece como ponto de partida uma determinada intenção técnica, que será diferenciada, instrumentalizada, capitalizada, simbolizada, animada de valores e conflitos pela instituição de um campo de culturas humanas. Esta colocação em patrimônio de procedimentos, recursos da fala, de comunicação e de sinergias locais é também o tempo de ajustamentos aos tempos profissionais e internos - de si próprio e dos outros, os usos de si - de concordâncias internas de tempo, de "histórias" de situação, de operações simultâneas, de transmissão de aprendizagens, de aprendizagem dos valores dos outros. Aqui pode-se falar em "competências", que segundo ele, é algo mais do que um mero acúmulo de experiências construídas no meio de trabalho.

Na discussão sobre competência Schwartz (1998), vê a emergência de três pólos distintos: um relacionado aos saberes passíveis de conceitualização; outro referente à apreensão das dimensões históricas da situação; e um terceiro referente ao debate de valores em cada meio particular. Existe então, uma variabilidade constitucional do próprio meio que requer que as pessoas recorram à originalidade de suas experiências e nelas encontrem os recursos para enfrentar o que há de inédito na situação. Estes recursos serão a linguagem, os valores, o uso "industrioso de si", os outros momentos 
da vida biológica, psíquica, cultural, as múltiplas circulações que aí existem, ou seja, "competências para viver" que cada indivíduo põe em prática de maneira diferente. Conclui-se daí que, se há indeterminação na definição de toda situação de trabalho há, por conseqüência, um mal estar em tentar definir objetivamente as "competências" que são a elas correlacionadas. Identifica-se, por conseguinte, um jogo delicado entre vários ingredientes:

- um primeiro, relacionado aos conceitos, à concepção, as modelizações que antecipam a realidade;

- um segundo ingrediente, relacionado à história própria de cada ambiente e ao acervo de capacidades utilizado para tomar decisões, para arbitrar levando em conta estas conjunturas;

- um terceiro, relacionado à possibilidade de estabelecer uma consonância entre estes dois primeiros no que se refere à capacidade de atualização em função das circunstâncias;

- um quarto ingrediente, relacionado aos "patrimônios", às estratégias acumuladas, às astúcias, às micro inventividades do coletivo;

- um quinto, que se refere à cultura histórica entronizada nos sinais que adquirem para cada pessoa um valor patrimonial; e

- um sexto ingrediente, que tem a ver com uma qualidade sinérgica que está presente nas cooperações locais, resultado da combinação fecunda de espectros diferentes de ingredientes.

Na conjugação destes ingredientes há uma temporalidade vivida nas tentativas de controle das variabilidades e complexidades do meio, e cuja duração média não pode ser antecipada, pois muda conforme as pessoas. Vale ressaltar ainda que, segundo essa ótica, a gestão dos diferentes ingredientes que forma a competência é feita pelos próprios sujeitos no momento mesmo em que se dá a atividade.

A solicitação para colocação em curso dessas competências é percebida nos mais variados postos de trabalho, mas ela é mais acentuada nas empresas de serviço. Numa tentativa de classificação pode-se dizer que a competência é solicitada principalmente em dois campos: na antecipação, preparação e viabilização de inovações e na resposta direta aos clientes através de qualquer atividade de prestação de serviço. Essa competência pode ser solicitada tanto pelos consumidores quanto pelos profissionais que devem responder a um evento e julgar sua próxima ação com rapidez. É neste caso que a camareira, e o funcionário de front office em geral, se encontra, pois na relação com o cliente, o dia a dia é repleto de eventos e singularidades. A qualidade do serviço, portanto, nada mais é que a expressão de competência da pessoa (por intermédio da ativação dos ingredientes citados) que compreende o cliente, e encontra na situação uma solução mais adequada.

Zarifian (2001) afirma que existem problemas que devem ser acompanhados em tempo real. Em épocas de alta temporada, como Carnaval e Ano Novo, a governança deve gerenciar variabilidades e ser capaz de atender aos hóspedes rapidamente e com o menor número de ocorrências. $\mathrm{O}$ acompanhamento próximo leva a uma rápida resolução do problema, atendendo melhor ao hóspede, que fica mais satisfeito e, conseqüentemente, fidelizado. O que torna possível esta interação é o desenvolvimento das competências e principalmente, as habilidades de comunicação. De maneira similar, ocorre o mesmo fenômeno no restaurante, quando o cliente encontra algum problema de higiene em sua refeição. $\mathrm{O}$ atendente deve compreender essa queixa como um problema não só para $\mathrm{o}$ cliente em si, como também para a imagem do restaurante. A maneira como o caso será encaminhado dependerá exclusivamente da atitude tomada pelo funcionário. Se este agir com descaso, poderá incentivar no cliente um sentimento de desprezo afetando sua percepção de qualidade, o que em última instância pode levar a perda irreversível deste cliente e de outros em potencial. Por outro lado, o caso será bem conduzido se o funcionário fizer um convite ao cliente para conhecer as dependências da cozinha, as preocupações com higienização e qualidade, o que poderá acarretar até mesmo numa fidelização do cliente. 
Como se pode depreender da discussão sobre competências aqui apresentada, qualidade e eficácia são determinadas pela atuação dos funcionários que geram o serviço prestado e influenciam diretamente a percepção final do cliente. Preocupar-se com gestão da qualidade significa gerenciar também a não qualidade, pois, diferentemente de operações fabris, onde o produto defeituoso pode ser descartado antes de chegar às mãos do cliente, em serviços, ela é detectada já no momento da sua realização. Os padrões de qualidade percebidos pelos clientes tratam de avaliar uma série de questões complexas que dizem respeito à quantificação de valores individuais e "sem dimensão", como conforto e prazer. Este forte aspecto de relacionamento entre pessoas é responsável pela imprevisibilidade e pela variabilidade que permeiam as ações, as reações, as expectativas e as situações pessoais no serviço. Esse aspecto é um dos fortes motivos que levam à dificuldade em padronizar alguns processos e, conseqüentemente, em quantificar a eficácia e a qualidade.

A relação do crescimento das vendas com a qualidade é um ponto relevante abordado por Zarifian (2001), pois aí podem se dar muitas degradações. O primeiro ponto de degradação do equilíbrio dessa relação ocorre nos dias em que o hotel está muito cheio (nos períodos de alta temporada) e os camareiros(as) não conseguem realizar as tarefas que exigem mais capricho e detalhe. Já no restaurante, o incremento nas vendas não é tão percebido como um ponto de degradação, pois ele conta com uma infra-estrutura adaptada para a sua capacidade máxima. O segundo ponto de degradação se dá na dificuldade do sistema técnico em acompanhar a expansão das vendas. No restaurante, ele é percebido quando o sistema de pagamentos não funciona adequadamente, acarretando longas filas para o cliente. A análise da atividade constatou que nas temporadas de maior clientela o carrinho utilizado pelo camareiro(a) não comporta a quantidade suficiente dos itens para a arrumação, levando o camareiro(a) a parar seu trabalho e repor seu estoque. Já o terceiro aspecto de degradação ocorre na dificuldade de registrar e antecipar os problemas, quando, por exemplo, o restaurante trabalha no seu limite máximo e precisa monitorar o número de mesas disponíveis. No hotel, uma ferramenta criada para contornar esta situação é o preenchimento do Relatório da Discrepância como uma tentativa de monitorar os problemas ocorridos.

\subsection{Análise da produtividade por meio da avaliação multicritério}

Para tentar formular um modelo de avaliação de produtividade que permita variações de acordo com cada setor, Gadrey (2001) propôs um quadro com uma avaliação multicritério do produto e dos desempenhos de uma atividade de serviço. Esta proposta pretende favorecer uma avaliação mais completa que não contemple somente critérios de produtividade e rentabilidade, critérios esses que são mais comumente utilizados no universo industrial e comercial. O quadro nos permite verificar a ênfase dos produtos e desempenhos diretos (relacionados ao fluxo de problemas ou operações de serviços), e os efeitos e impactos de longo prazo sobre o estado das realidades tratadas. Os pesos dados aos critérios utilizados variam de acordo com os objetivos de desempenho de cada empresa. Estes parâmetros são divididos em seis grupos e devem ser adaptados para cada setor. São eles:

1. Critérios técnicos ou industriais: são aqueles que ressaltam as características técnicas da organização, que podem ser um diferencial para seus consumidores.

2. Critérios comerciais ou financeiros: avaliam o estado financeiro do negócio, ou seja, como a administração financeira vem sendo feita. Além disso, se preocupa em fazer mensurações mais objetivas, tais como: custo médio, receita total, receita média por cliente, identificação do públicoalvo, etc.

3. Critérios de relacionamento: podem se subdividir em três vertentes: o relacionamento do estabelecimento com seus clientes, com seus funcionários e com outras empresas.

4. Critérios cívicos e ecológicos: levam em consideração os benefícios gerados para a sociedade em que a organização está inserida, ou seja, como a organização afeta todos os seus stakeholders. Para isso avalia investimentos em infra-estrutura, a contribuição para o desenvolvimento de uma região, o 
crescimento de um mercado local, o impacto do negócio no meio ambiente assim como sua preservação, entre outros.

5. Critérios de criatividade e inovação: avaliam quais serão os novos produtos e serviços que serão lançados no mercado, as necessidades de seus consumidores, a capacidade da organização de adquirir o conhecimento necessário às constantes modificações a que será submetida, etc.

6. Critérios de imagem e de reputação: procuram traduzir como a organização pode levar ao público a imagem que deseja e como trabalhar seu marketing.

Segue abaixo a configuração visual do modelo do quadro de avaliação multicritério proposto por Gadrey:

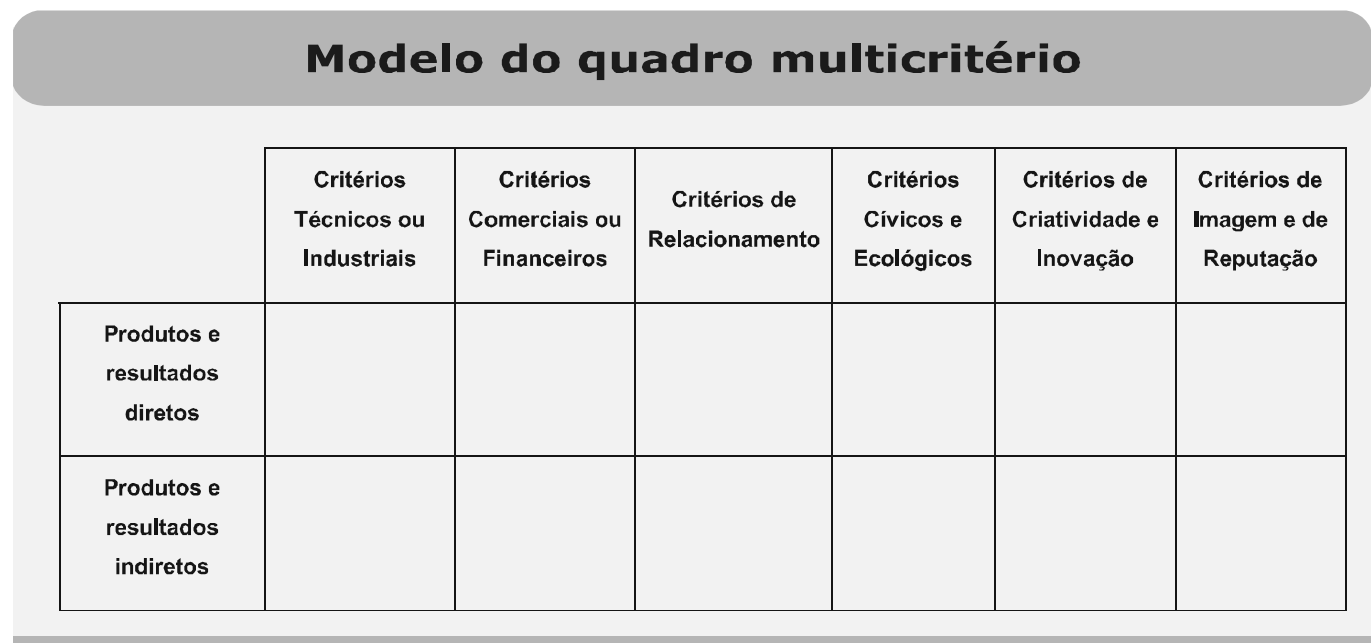

Figura 6 - Modelo do quadro multicritério proposto por Gadrey (2002)

Propõe-se aqui uma adaptação da grade apresentada por Gadrey (2001) ao setor hoteleiro e ao setor de restaurantes levando em consideração as atividades identificadas pelos atores participantes (clientes) da avaliação de desempenho. Apresenta-se nas figuras 7 e 8 um resumo desta adaptação abordando três dos seis critérios. Estes critérios são analisados quanto aos seus produtos e resultados indiretos.

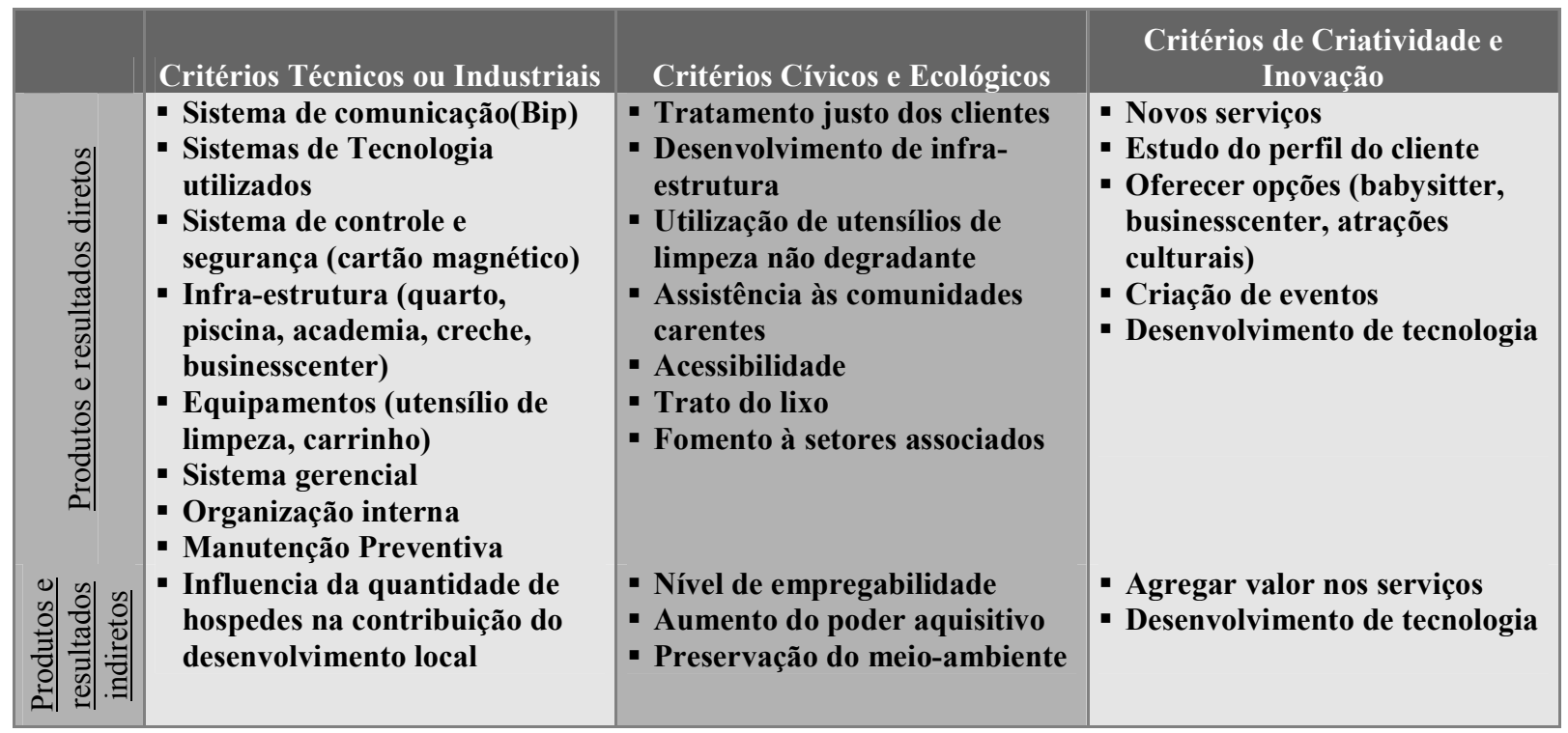

Figura 7 - Avaliação multicritério do setor hoteleiro 


\begin{tabular}{|c|c|c|c|}
\hline & Critérios Técnicos ou Industriais & Critérios de Relacionamento & $\begin{array}{l}\text { Critérios de Imagem e de } \\
\text { Reputação }\end{array}$ \\
\hline 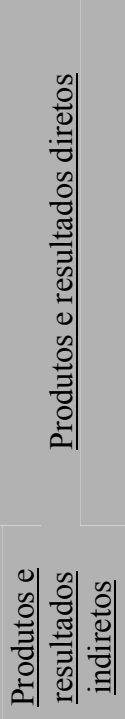 & $\begin{array}{l}\text { - Sistema de porções } \\
\text { - Mix de Serviços oferecidos } \\
\text { (café da manhã, almoço e } \\
\text { sanduíche) } \\
\text { - Filas múltiplas } \\
\text { - Sistemas informatizados de } \\
\text { controle de estoque, comandas } \\
\text { e pagamentos } \\
\text { - Organização interna através } \\
\text { de mapa de tarefas } \\
\text { - Multifuncionalidade } \\
\text { - Insumos de qualidade } \\
\text { - Plano de higienização } \\
\text { - Mesas Disponíveis } \\
\text { - Quantidade de pessoas } \\
\text { servidas } \\
\text { - Desenvolvimento de } \\
\text { fornecedores da região } \\
\text { - Desenvolvimento de tecnologia }\end{array}$ & $\begin{array}{l}\text { - Serviços diferenciados } \\
\text { - Precupação com a formação } \\
\text { dos funcionários } \\
\text { - Relacionamento interpessoal } \\
\text { - Ambiente familiar no } \\
\text { relacionamento com os } \\
\text { funcionários } \\
\text { - Personalização no tratamento } \\
\text { de novos clientes } \\
\text { - Parcerias com outras empresas } \\
\text { - Cardápio via Internet } \\
\text { - Assistência aos funcionários } \\
\text { - Serviço de refeições para } \\
\text { viagem } \\
\text { - Geração de comportamento de } \\
\text { fidelidade } \\
\text { - Aumento do nível de formação } \\
\text { dos funcionários }\end{array}$ & $\begin{array}{l}\text { - Higiene e limpeza das } \\
\text { instalações } \\
\text { - Manter contato com cliente } \\
\text { para entender suas } \\
\text { necessidades } \\
\text { - Refeições saudáveis } \\
\text { - Insumos de qualidade } \\
\text { - Atendimento personalizado } \\
\text { para os problemas } \\
\text { - Foco no cliente } \\
\text { - Ambiente agradável }\end{array}$ \\
\hline
\end{tabular}

Figura 8 - Avaliação multicritério do setor alimentício

No critério técnico ou industrial do hotel pode-se citar os sistemas de tecnologia utilizados e o controle de fluxo de pessoas como os mais em voga atualmente. No restaurante, o ponto chave é gestão dos fluxos essenciais para o diferencial da empresa.

Nos critérios de relacionamento a empresa busca serviços diferenciados de modo a atender às necessidades de seus clientes e novamente recai na necessidade de conhecer profundamente seu público-alvo. Para criar um relacionamento agradável com seus funcionários, a empresa pode agir de diversas maneiras. Uma delas seria o investimento em assistência ao funcionário (saúde, formação, profissionalização). Funcionários bem relacionados com a empresa tendem a se tornarem mais solícitos na realização de suas tarefas e, conseqüentemente, com os clientes. O relacionamento com outras empresas tem se tornado cada vez mais freqüente sob a forma de parcerias. No caso do setor hoteleiro, é possível vislumbrar parcerias com empresas aéreas (para a própria tripulação, por exemplo), empresas de turismo, grandes empresas (para viagens de executivos e pessoal), entre outras. Empresas parceiras possuem a garantia de disponibilidade de quartos. Num restaurante, as parcerias também trazem diversos benefícios se, por exemplo, os funcionários das empresas localizadas nos arredores receberem descontos por freqüentarem o restaurante, criando assim uma rede de relacionamentos.

Como critérios cívicos para o hotel pensou-se na existência de um tratamento mais direcionado para determinados segmentos de clientes como, por exemplo, os deficientes físicos, que muitas vezes limitam suas excursões a localidades onde encontrem o mínimo de conforto. Sabe-se também que no desenvolvimento de certas regiões e de sua infra-estrutura local, o fomento a setores associados prevê a criação de verdadeiros conglomerados de empresas a partir do ramo hoteleiro e do turismo. Para que haja a venda de produtos tais como canetas, toalhas e canecas, é necessário que haja também um mercado local para a manufatura dos mesmos. Outros setores de prestação de serviço também se beneficiam com o crescimento do ramo hoteleiro, tais como as lavanderias, o setor de vestuário, $\mathrm{o}$ setor de equipamentos, o setor de telefonia, o setor médico, etc. O crescimento de um mercado local aumenta a empregabilidade e, conseqüentemente, beneficia a sociedade a médio e longo prazo.

Sob o ponto de vista ecológico, um hotel pode contribuir com o meio-ambiente local tratando seu lixo, utilizando produtos biodegradáveis ou evitando a descaracterização da região. Por exemplo, hotéis próximos a orla podem ser freqüentados tanto por mergulhadores quanto por praticantes de pesca 
submarina. Se houver pesca predatória na região, em pouco tempo este nicho mercadológico morrerá. O mesmo se aplica a alguns Spa's, que fornecem inúmeros tratamentos de beleza, mas não tratam os resíduos dos produtos químicos utilizados antes de lançá-los na natureza.

No restaurante, estes critérios são vistos principalmente em relação ao meio-ambiente e ao tratamento justo aos clientes. A preocupação com o tratamento dos dejetos gerados, com o não desperdício e com o próprio meio-ambiente através da utilização de utensílios de cozinha biodegradáveis são os aspectos que contribuem para a preservação ambiental.

O critério de criatividade e inovação exige que a empresa esteja sempre atualizada sobre as carências de seus clientes. O suprimento de necessidades agrega valor ao que é oferecido, entretanto, muitas vezes, é preciso investir em novas tecnologias. Algumas ações auxiliam a empresa a agregar valor e a atrair clientes. Elas estão intrinsecamente relacionadas com inovação e criatividade. Um exemplo identificado no estudo de caso 2 é a realização de eventos. Ao atrair um determinado público específico, o hotel cria oportunidades para divulgar seus serviços com a vantagem de um reconhecimento prévio de características que agradem. No primeiro estudo de caso, desde a idealização do negócio a inovação estava presente através de um sistema de porções. Ao longo do tempo, algumas modificações foram feitas de forma a adequar o restaurante a seus clientes como a oferta de sanduíches e café da manhã.

O último critério, de imagem e reputação, está relacionado às redes de renome a que pertencem às empresas estudadas, tanto o restaurante como o hotel. Entretanto, o fato de pertencerem a uma rede traz implicações de qualidade, uma vez que a imagem de uma filial reflete para o cliente a imagem de toda a rede. Aqui se avalia algumas ferramentas para divulgação de marketing, tais como certificações de qualidade, preocupação ambiental, fidelização, entre outras.

Todos estes critérios são também analisados quanto aos seus produtos e resultados indiretos. Neste caso, os parâmetros de ambas as empresas em muito se assemelham, pois essa avaliação indireta busca entender os impactos da ação daquela empresa na sociedade em que está inserida.

Os critérios, sugeridos anteriormente, procuram avaliar a produtividade de maneira irrestrita englobando diversos aspectos. Estes aspectos na verdade são definidos pela importância da empresa em ser eficiente e eficaz, mas principalmente, nos aspectos que mais influenciam o conceito de qualidade na ótica do cliente. O conceito de qualidade está ligado ao pacote de valor oferecido pela empresa e por isso deve ser analisado cuidadosamente. Para fazer gestão da qualidade deve-se considerar, além dos critérios sugeridos acima, a articulação entre capacidade produtiva - que inclui o gerenciamento de filas - com os objetivos de desempenho que definem a estratégia da organização. Tal estratégia tem como meta definir o grau de importância que cada ator terá no produto final da prestação de serviços.

\section{Comentários finais e pistas para a discussão em serviços}

Ao longo do texto procurou-se analisar alguns pontos que são fundamentais para a criação dos diferenciais em mercados concorrenciais nos ramos de negócios estudados e entender quais as práticas adotadas para este fim. Um dos objetivos foi procurar entender melhor a noção de excelência verificando como acontece a interação entre os diferentes universos de serviços, a influência da comunicação e das competências na geração de valor e, conseqüentemente, no alcance da qualidade estabelecida, e por fim, a importância de uma avaliação da produtividade adaptada à realidade de cada empresa. Tratou-se aqui de estudar dois grupos do setor serviço em expansão: o setor hoteleiro e de alimentação que, pela classificação de Gadrey (2001), são marcados por uma progressiva participação no emprego no setor terciário que pode estar associada a transformações estruturais de cunho econômico e social. O referencial teórico permitiu verificar a pertinência da adaptação dos modelos apresentados para analisar os dois casos dos setores escolhidos. Dessa forma foram elaborados quadros multicritério como proposta para a avaliação da produtividade. Mais uma vez comprovou-se que a singularidade de cada empresa no setor serviço exige a criação de referenciais específicos. 
A partir do modelo de serviços proposto por Zarifian (2002) foi possível definir as partes envolvidas na prestação de serviços e principalmente, quais aspectos das interações entre seus principais atores são relevantes na percepção de qualidade do cliente. Para fazer essa identificação é importante perceber o máximo possível de elementos do contexto da ação que envolve desde a comunicação até as competências exigidas para a realização das mais simples tarefas. Essencial também é estar atento para o fato de que funcionários e gestores são os grandes responsáveis pela gestão de competência que é feita permanentemente em toda situação de trabalho e que, em especial, no setor serviço, é parte intrínseca da qualidade. Dessa forma, por exemplo, o trabalho de uma camareira é bem avaliado se ela arruma o quarto de acordo com as especificações e atende bem ao cliente. Por outro lado, o setor hoteleiro pode ser avaliado se consegue melhorar o "estado de espírito" de seus hóspedes fazendo com que o cliente deixe o hotel com suas necessidades atendidas. É possível então questionar-se o real produto de um serviço prestado em hotelaria, pois, pode-se interpretar a satisfação do cliente de diversas maneiras considerando-se a incerteza da referência temporal. Tal referência também traz incertezas na avaliação do produto do restaurante, onde também se faz valer o questionamento de quais as reais necessidades os clientes buscam suprir, sejam elas objetivas ou subjetivas. $O$ restaurante é avaliado não só pelo produto servido como também pelo atendimento rápido e de qualidade e por sua infra-estrutura.

Este panorama aponta a complexidade em se avaliar a produtividade em serviço. A avaliação de produtividade também está relacionada com o horizonte temporal de referência, pois é possível definir diferentes metas em temporalidades distintas com produtos imediatos ou indiretos. É necessário saber o fluxo de atividade dos prestadores de serviços para definir o produto final, criando assim os indicadores de melhoria do estado da situação tratada. A partir deste fluxo, é possível fundamentar critérios que avaliem o interesse pelo serviço e seus resultados, ou seja, o real valor do serviço. Uma primeira conclusão é a de que a avaliação da produtividade está relacionada a uma das dificuldades de gestão do setor de serviço: estabelecer as ferramentas de abordagem quantitativa, qualitativa e econômica. A dificuldade em quantificar indicadores leva à complexidade na mensuração da eficiência e eficácia. O controle da eficiência pode ser entendido então como a relação entre os resultados obtidos e os recursos mobilizados. Geralmente, são admitidas pressuposições reducionistas quanto às condições reais da empresa no âmbito geral, sem a utilização de referenciais constantes. A dimensão qualitativa é parte inseparável das atividades de serviço. Para avaliar a eficiência de um segmento deste setor é necessária a análise de caso por caso da prestação, devido a dificuldade de padronização dos processos e impossibilidade somente do uso de indicadores econômicos quantitativos. É necessário levar-se em conta a experiência, conhecimento e competências dos diferentes sujeitos envolvidos na atividade.

Percebe-se então a urgência de focar a singularidade de cada situação específica e a adoção de avaliações pluralistas para poder analisar adequadamente o setor serviço. Como visto anteriormente, a primeira dificuldade encontrada está na definição do produto do serviço, uma vez que várias definições são admissíveis e nenhuma se impõe naturalmente, o que se deve à fraca padronização dos processos, da própria prestação dos serviços e dos resultados. As inúmeras possibilidades de execução dos serviços dificultam a classificação da prestação de serviços em casos padrões. Por esta ausência de grupos bem definidos, os serviços permanecem heterogêneos, dificultando uma nomenclatura classificatória. Esta falta de padronização se deve ao fato de haver a prestação face a face, ou seja, há o relacionamento entre pessoas, o que traz a imprevisibilidade e variabilidade das ações, reações e expectativas nas situações pessoais dos serviços.

Conclui-se daí que é impossível formular um modelo único que avalie a produtividade em qualquer empresa de serviços e até mesmo em um único setor. A avaliação da produtividade, na verdade, deve ser adaptada à realidade em que cada empresa está inserida, levando em consideração os objetivos de desempenho e os anseios do seu público-alvo. Nos estudos de caso analisados aliou-se teoria à prática, propondo alguns critérios que pudessem ser aplicados em cada um dos negócios estudados. A elaboração de diferentes quadros de multicritério, mesmo para empresas que possuem inúmeros pontos em comum, comprova que a singularidade de cada empresa deste setor exige a criação de referenciais específicos que avaliem a produtividade. 
A percepção da existência desta singularidade deve-se, em parte, a uma característica comum aos serviços do setor terciário em crescimento: possuir a comunicação como componente essencial. Ou seja, onde são intensas as relações de serviços com interação de informações, contatos e trocas interpessoais entre produtores e beneficiários. Outra característica desse grupo de serviços é que as inovações tecnológicas tornam-se um complemento à atividade fim, não significando uma substituição ao trabalho realizado e sim um aumento de qualidade do serviço prestado. Os serviços onde o componente comunicacional não é tão significativo (serviços de distribuição, transportes, correio, seguros) têm sido progressivamente substituídos pela automação. É nesse contexto que compreende-se a importância das atividades de linha de frente (representados pelas camareiras(os) e atendentes) como melhoria do desempenho da produtividade do setor de serviços como um todo. Pois no universo de serviços, a singularidade de uma empresa, um processo ou uma pessoa é que determina seu real valor para o cliente final.

Essa singularidade está fortemente implicada com os três universos apontados por Zarifian (2002) como componentes do modelo de serviços: suporte técnico, relacionamento face à face com o cliente e percepção de sua necessidade. Concorda-se inteiramente com o autor de que a noção de eficácia será estabelecida pela qualidade na interação entre esses três universos. O atendimento a eles está intimamente ligado a idéia de "proposta de valor", que considera como valor agregado o fato do cliente ter suas condições de atividade modificadas positivamente. Entretanto há risco nesse processo, pois a proposta de valor pode estar mal ajustada à realidade de uso valorizada por uma categoria de clientes.

Conclui-se, então, que a dificuldade de quantificação encontrada neste segmento, em virtude da ampla importância de suas características qualitativas, é um fator que merece atenção especial e é responsável por tornar essa discussão, tão instigante. Discussão que procura enfrentar o desafio do estabelecimento de critérios de produtividade para o setor serviço sem deixar de considerar os fatores relacionados entre a proposta de valor oferecida e a interação entre as atividades de linha de frente e retaguarda.

\section{Referências}

BOMFIM, C.; ERBISTI, B.; ROCHA, C. Serviços: uma análise de produtividade e qualidade nos setores de hotelaria e alimentação. Projeto final de Engenharia de Produção - Universidade Federal Fluminense. 2004.

ALVAREZ, D.; ERBISTI, B.; BOMFIM, C. et al. Análise Ergonômica do Trabalho de Camareiras de um Hotel de Luxo. In: XXIII Encontro Nacional de Engenharia de Produção - ENEGEP, Ouro Preto, 2003. Anais do encontro. Minas Gerais: Universidade Federal de Ouro Preto, 2003, CD-Rom.

ALVAREZ, D.; ERBISTI, B.; BOMFIM, C. et al. Aspectos de Produção e Formação: o trabalho de camareiras em um hotel de luxo. X Simpósio em Engenharia de Produção - SIMPEP, Bauru, 2003. Anais do encontro. São Paulo: Universidade de Bauru, 2003, CD-Rom.

CAON, M., CORRÊA, H. Gestão de Serviços: lucratividade por meio de operações e de satisfação dos clientes. São Paulo: Atlas, 2002. 480p.

GADREY, J. Emprego, produtividade e avaliação de desempenho dos serviços. In: SALERMO, Mario (org.) Relação de Serviço - produção e avaliação. São Paulo: Senac, 2001. p.23-66.

LACOSTE, J. Fala, atividade, situação. In: DUARTE, Francisco et al. (org.) Linguagem e Trabalho, Rio de Janeiro: Lucerna, 1998. p.15-36.

SCHWARTZ, Y. et al. Partie II - Analyse des Activités de Travail et Pertinence des Ratios Economiques. In: SCHWARTZ et al. (org) Raport Final de la Recherche L'évaluation Economique a 
L'épreuve des Services - L'activité entre Efficacité et Efficience. Aix en Provence: Centre APST Recherche, 1992. 250p.

SCHWARTZ, Y. Os ingredientes da competência: um exercício necessário para uma questão insolúvel. Educação \& Sociedade, ano XIX, nº 65, Dez. 1998.

SLACK, N.; CHAMBERS, S.; JOHNSTON, R. Administração da Produção. São Paulo: Atlas, 2002.

VIDAL, M.; MUNIZ, H.; ALVAREZ, D. Terá a atividade um lugar na avaliação de performance do Setor de Serviços? Revista Ação Ergonômica - A interdisciplinariedade da ergonomia, vol.1 $\mathrm{n}^{\mathrm{o}} 2$, p.82-94. Nov. 2001.

WISNER, A. Organização do Trabalho, carga mental e sofrimento psíquico. In: FERREIRA, Leda Leal (org.) A inteligência no Trabalho, São Paulo: Fundacentro, 1994. p.11-20.

ZARIFIAN, P. Mutação dos Sistemas Produtivos e Competências Profissionais: A Produção Industrial de Serviço". In: SALERMO, Mario Sergio (org.) Relação de Serviço - produção e avaliação, São Paulo: Senac, 2001(a).p.67-94.

ZARIFIAN, P. Valor, Organização e Competência na Produção de Serviço - Esboço de um Modelo de Produção de Serviço. In: SALERMO, Mario Sergio (org.) Relação de Serviço - produção e avaliação, São Paulo: Senac, 2001(b) p.95-150.

ZARIFIAN, P. et GADREY, J. L'émergence d'un modèle du service: enjeux et realités. Paris: Liaisons, 2002.174p.

ZARIFIAN, P. Objetivo competência - por uma nova lógica. São Paulo: Atlas, 2001(c). 200p. 